\title{
Investigation of the Similarities of Industrial Wood Production Statistics of Regional Directorates of Forestry in Turkey Using Cluster and Discriminant Analysis
}

\author{
İlker AKYÜZ ${ }^{*} \oplus$, Nadir ERSEN²®, Bahadır Çağrı BAYRAM ${ }^{3} \odot$, Mustafa $\mathrm{ACAR}^{4} \oplus$, \\ Kadri Cemil AKYÜZ1 ${ }^{1}$, Tutku ÜÇÜNCÜ \\ ${ }^{1}$ Karadeniz Technical University, Department of Forest Industry Engineering, Trabzon, TURKEY \\ ${ }^{2}$ Artvin Çoruh University, Forestry and Forest Products, Artvin, TURKEY \\ ${ }^{3}$ Kastamonu University, Forest Industry Engineering, Kastamonu, TURKEY \\ ${ }^{4}$ Artvin Çoruh University, Faculty of Forestry, Forest Engineering, Artvin, TURKEY \\ ${ }^{*}$ Corresponding Author:iakyuz@,ktu.edu.tr
}

Received Date: 01.03.2018

Accepted Date: 10.06 .2019

\section{Abstract}

Aim of study: In this study, the amount of industrial wood production of the regional directorates of forestry in Turkey was examined deeply and the similarities between the regional directorates in industrial wood production were investigated by cluster and discriminant analysis.

Area of study: The study area is regional directorates of forestry in Turkey.

Material and Method: Seven different variables were used to construct similar clusters. The arithmetic mean of these seven variables was taken for 4 years (2013-2016). Cluster and discriminant analysis were used as method.

Main results: According to the clustering analysis results, it was determined that regional directorates of forestry could be divided into maximum 6 and minimum 2 groups. As a result of the discriminant analysis conducted to determine the highest success of the groupings, it was determined that the regional directorates of forestry distinguished in $100 \%$ success in 6 groups. Also, it was found that a Kastamonu regional directorate of forestry, which has the highest value in industrial wood production, has formed a group alone.

Highlights: For the production of industrial wood, the regional directorates of forestry can put more emphasis on the use of forest areas. Thus, we can avoid the dependence on foreign sources.

Keywords: Industrial Wood, Cluster Analysis, Discriminant Analysis.

\section{Türkiye'de Orman Bölge Müdürlüklerinin Endüstriyel Odun Üretim Miktarı İstatistiklerinin Benzerliklerinin Kümeleme ve}

\section{Diskriminant Analizi ile Araştırılması}

$\ddot{O} \mathbf{z}$

Çalışmanın amacl: $\mathrm{Bu}$ çalş̧mada orman bölge müdürlüklerinin endüstriyel odun üretim miktarları detaylı bir şekilde incelenmiş olup, endüstriyel odun üretimi bakımından bölge müdürlüklerinin benzerlikleri küme ve diskriminant analiz yardımıyla araştırılmış̧ır.

Çalışma alanı: Türkiye'deki orman bölge müdürlükleri çalışma alanını oluşturmaktadır.

Materyal ve Yöntem: Benzer özellikleri taşıyan kümeleri oluşturmak için yedi farklı değişken kullanılmıştır. Bu değişkenlerin 2013-2016 yıllarındaki değerlerinin ortalaması alınmıştır. Araştırma yöntemi olarak ise kümeleme analizi ve diskriminant analizi kullanılmıştır.

Sonuçlar: Kümeleme analizi sonucuna göre, orman bölge müdürlüklerini en fazla 6 ve en az 2 gruba ayrılabileceği tespit edilmiştir. Oluşturulan gruplamalardan en yüksek başarıyı belirlemek için yürütülen ayırma analizi sonucunda orman bölge müdürlüklerinin 6'li gruplamada \%100 başarı elde ettiği saptanmıştır. Ayrıca, endüstriyel odun üretiminde en yüksek değere sahip olan Kastamonu orman bölge müdürlüğünün tek başına bir grup oluşturduğu bulunmuştur.

Önemli Vurgular: Endüstriyel odun üretimi için orman bölge müdürlükleri orman alanlarının kullanımı ile ilgili çalışmalara daha fazla önem vererek dışa bağımlılığın önüne geçebiliriz.

Anahtar kelimeler: Endüstriyel Odun, Kümeleme Analizi, Diskriminant Analizi. 


\section{Introduction}

In Turkey, $28.6 \%$ of the total land area (22.3 million hectares) of Turkey is covered by forests. Forest areas without trees are not included in these areas. However, while $73 \%$ of Turkey's forests are high forests, others are coppice forests and $43 \%$ of these forests are degraded forests (GDF, 2015).

The forests that cover $28.6 \%$ of the country have many benefits. Forests in first years meet the needs of people such as sheltering, hunting and wood. Today, the way people take benefit of the forests and the priority of benefit from forests has changed a lot. The briefly known benefits of forests are as follows: (1) they are raw material and water storages, (2) they positively affects the climate, (3) they protect the soil, (4) they recreation area, (5) they are the source of oxygen, (5) they are the work place for people, and (6) they are the natural living place of wildlife (URL-1, 2017).

The products supplied from the forest are divided into primary and secondary forest products. Primary forest products consist of the industrial wood and firewood raw materials.

Industrial wood raw material used as intermediate goods in many industries such as manufacturing industry, mining and construction and it consists of log, mining pole, other industrial wood, pulpwood, fibrechip wood, pole and wire pole (Güngör, Kayacan, \& Korkmaz, 2004).

In recent years, there has been a serious increase in industrial wood production in Turkey depending on the increased capacity of the industry, growth potential in the construction sector and positive economic developments in General Directorate of Forestry (GDF). The production amount of industrial wood produced by GDF in Turkey is 17 million $\mathrm{m}^{3}$ in 2016, while it was 7 million $\mathrm{m}^{3}$ before 2002 (Figure 1). In the other words, the amount of industrial wood in Turkey increased by approximately $143 \%$ and according to 2016 data, $42 \%$ of industrial wood production is fibre-chip wood, $33 \%$ is $\log , 15 \%$ is pulpwood, and $10 \%$ is others (Anonymous, 2016; URL-2, 2017).

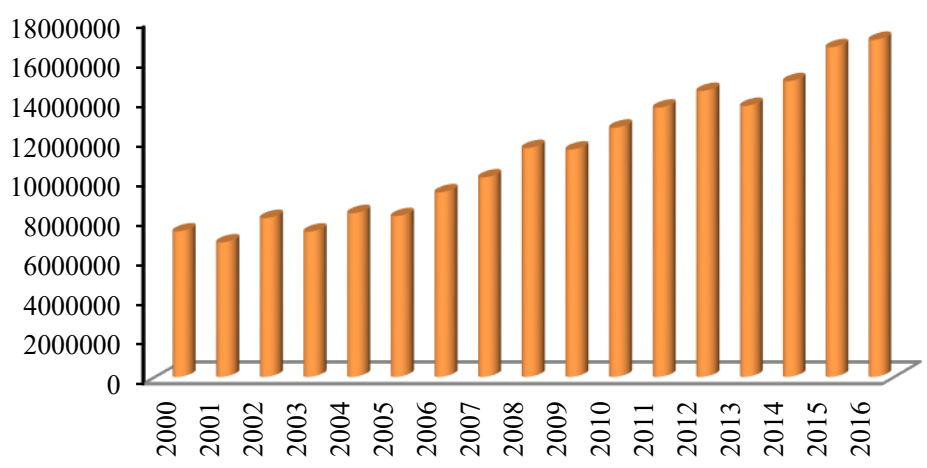

Figure 1. Amount of industrial wood production $\left(\mathrm{m}^{3}\right)$

According to 2015 data, about 21.7 million $\mathrm{m}^{3}$ of industrial wood is produced in Turkey. 16.6 millionm $^{3}$ of this production is made by the General Directorate of Forestry, 3.5 million $\mathrm{m}^{3}$ by the private sector. The rest of the production is imported. $51 \%$ of the industrial wood raw material imports in our country are made from Ukraine. More than $90 \%$ of the industrial wood produced outside the state forests consists of rapidly growing tree species such as poplar, eucalyptus. In terms of tree species, approximately $77 \%$ of GDF production constitutes coniferous species (Anonymous, 2016).

Also, in Turkey, about 29 million $\mathrm{m}^{3}$ of round wood is consumed and $66 \%$ of which is provided by state forests. $77 \%$ of industrial wood is provided by sales from General Directorate of Forestry (GDF), 15\% from private sector sales and $8 \%$ by import (Anonymous, 2016). 


\section{Literature Search}

There are many studies on clustering and discriminant analysis and trade made in the field of forest products and furniture industry.

Akyüz, Cindık, Serin \& Akyüz (2002b) investigated exports and imports total prices of forest product industry in the East Black Sea region according the data obtained from the Customs Manager. In the present paper, the development of the forestry industry enterprises in the 63 settlements in the Eastern Black Sea Region was investigated by using 32 variables. Discriminant Analysis method was used to evaluate the data (Akyüz, Cındık, Akyüz \& Serin, 2002a). Akyüz (2006) evaluated the production, export and import values of 12 different product groups in the field of timber, wood board and paper products of Turkey and 25 different European Union countries using the hierarchical cluster and the discriminant analysis. Yıldırım, Akyüz, Gedik, Balaban \& Çabuk (2008) tried to show to the position of Turkey among the member countries of the EU by using the hierarchical cluster and the discriminant analysis in terms of some product groups belonging to wood based panel industry situated in the forest products industry. In another study, the position of Turkey among the member countries of the EU by using the hierarchical cluster and the discriminant analysis in terms of some product groups belonging to the wood based panel industry situated in the forest products industry was investigated (Akyüz and Yıldırım, 2009). Bojnec and Fertö (2011) was investigated Austrian bilateral trade in raw and semi-finished wood products (AFWPs) with Hungary and Slovenia, respectively. As a result, raw and semifinished wood products are among the most significant single traded AFWPs of Hungary and Slovenia with Austria. Hungary is a net exporter of raw and semi-finished wood products to Austria while Slovenia is a net importer of raw and semi-finished wood products from Austria. Akyüz, Balaban \& Yildırım, (2012) determined the place and importance of forest products industry in the manufacturing industry by means of balance sheet ratios. In evaluating these financial ratios, they used the hierarchical cluster and the discriminant analysis. They decided to divide the industrial branches into 3 homogeneous groups and found that the forest products industry was in the third group. In the other paper done by Bojnec and Fertö (2014), was analysed the forestry industry trade of the New Member States (NMS-11) of the European Union (EU) on the enlarged EU-27 markets. Tiryaki, Aydın \& Üçüncü (2015), determining the status within the European Union members of Turkey furniture sector using hierarchical clustering analysis was aimed. Sujova, Hlavackova \& Marcinekova (2015) was aimed to evaluate the impact of foreign trade in wood processing industry on the economic performance of the sector in Slovakia and the Czech Republic. It was found that in Slovakia and the Czech Republic, the foreign trade in the wood processing industries play a significant role on the economic performance. The aim of this paper is to analyse trade performance and competitiveness of the Slovak wood processing industry sectors and their comparison with the Visegrad group (Poland, Czech Republic and Hungary) countries (Palus, Parobek \& Liker, 2015). The objective of paper done by Koebel, Levet, Van, Purohoo \& Guinard (2016) was to analyse the role of the forest resource endowment for explaining wood products trade as well as, beyond the resource endowment, to explore the role of other determinants reflecting the industrial performance of sectors. Alem (2016) aimed to evaluate the trends of expenses from importing and incomes generated from exporting different processed wood products, to assess the processed wood products trade balance, and to forecast future expenses in importing processed wood products. Import and export data of processed wood products in the years of 2005-2013 was used for this. It was found that the self-insufficiency of the Ethiopia in producing different processed wood products and the heavy expenditure to import wood products to fill the gap. Akyüz, Yıldırım, Tugay, Akyüz \& Gedik (2016) aimed to determine how the hazard classes varied within the manufacturing industry depending on years and how the forest products industry sub-sectors took place in 
this change using the hierarchical cluster and the discriminant analysis. They found that the three sub-sectors of the forest products industry (wood products and cork, paper and paper products and furniture sectors) are included in the same cluster. This paper was analyzed the international trade in forest products from 2000 to 2014 and emphased Brazil's role (Maxir and Masullo, 2017).

In this study, in terms of the industrial wood production, the similarities between the regional directorates of forestry were investigated by cluster and discriminant analysis.

\section{Material and Method \\ Material}

Although there are 27 Regional Directorate of Forestry in Turkey, data related to Şanliurfa Regional Directorate not be obtained. In the study, 26 Forestry Regional Directorate and the production quantities of the seven product groups (log, telephone pole, mining pole, other industrial wood, pulpwood, fibre-chipwood and pole), which form the industrial wood group are taken into consideration in terms of 2013, 2014, 2015 and 2016 years. Then, the mean values of these four years were used in the statistical analyzes to be performed. The free data was filled out with gives number 1.These data used in the study were obtained from the website of the General Directorate of Forestry (GDF, 2017). Making clusters of forest district directorates based on total amount of industrial wood production may not give realistic and meaningful results. For this, it is possible to give more realistic results in clustering analysis by writing the production quantities of the products forming the industrial wood group, separately. These seven product groups, which form the industrial wood group, constitute the decision variables of the study. Also, it can be determined which product is more important in industrial wood production by taking each product constituting the industrial wood group as a decision variable.

Table 1. The average values of forest regional directorates for selected years (2013-2016)

\begin{tabular}{lccccccc}
\hline $\begin{array}{c}\text { Regional } \\
\text { Directorates of } \\
\text { Forestry }\end{array}$ & $\begin{array}{c}\text { Log } \\
\left(\mathrm{m}^{3}\right)\end{array}$ & $\begin{array}{c}\text { Telephone Pole } \\
\left(\mathrm{m}^{3}\right)\end{array}$ & $\begin{array}{c}\text { Mining } \\
\text { Pole } \\
\left(\mathrm{m}^{3}\right)\end{array}$ & $\begin{array}{c}\text { Other Industrial } \\
\text { Wood } \\
\left(\mathrm{m}^{3}\right)\end{array}$ & $\begin{array}{c}\text { Pulp } \\
\text { Wood } \\
\left(\mathrm{m}^{3}\right)\end{array}$ & $\begin{array}{c}\text { Fibre- } \\
\text { Chip } \\
\left(\mathrm{m}^{3}\right)\end{array}$ & $\begin{array}{c}\text { Pole } \\
\left(\mathrm{m}^{3}\right)\end{array}$ \\
\hline Adana & 272810 & 806 & 69511 & 117107 & 10591 & 273093 & 156 \\
\hline Sakarya & 108829 & 1 & 644 & 31579 & 71612 & 280889 & 24 \\
\hline Amasya & 162897 & 2113 & 10550 & 39937 & 42588 & 559495 & 117 \\
\hline Ankara & 95207 & 2523 & 13119 & 495 & 63576 & 171378 & 1297 \\
\hline Antalya & 356214 & 243 & 62354 & 41486 & 110769 & 274707 & 116 \\
\hline Artvin & 93160 & 8 & 760 & 1892 & 32640 & 12963 & 1 \\
\hline Balikesir & 262863 & 744 & 31520 & 35237 & 188531 & 444996 & 473 \\
\hline Bolu & 484910 & 3574 & 11851 & 5662 & 301365 & 305256 & 306 \\
\hline Bursa & 274329 & 2169 & 17450 & 40744 & 163147 & 300728 & 90 \\
\hline Kayseri & 41468 & 8589 & 21531 & 1537 & 13532 & 49030 & 40 \\
\hline Denizli & 199713 & 4317 & 51131 & 25496 & 36400 & 282658 & 1516 \\
\hline Elaziğ & 219 & 1 & 436 & 90 & 96 & 9936 & 45 \\
\hline Erzurum & 43060 & 1041 & 7763 & 4338 & 19384 & 6353 & 1210 \\
\hline Eskişehir & 38598 & 1778 & 10367 & 3176 & 36870 & 123718 & 348 \\
\hline Giresun & 181126 & 2047 & 8798 & 10310 & 58133 & 219753 & 813 \\
\hline Isparta & 145546 & 800 & 19948 & 8084 & 60690 & 148623 & 64 \\
\hline Istanbul & 192480 & 1 & 40916 & 40210 & 52465 & 458381 & 11 \\
\hline Izmir & 242833 & 407 & 21318 & 127766 & 98408 & 494023 & 345 \\
\hline K.Maraş & 108108 & 300 & 26320 & 30552 & 6917 & 163132 & 66 \\
\hline & & & & & & & \\
\hline
\end{tabular}


Table 1 (continued)

\begin{tabular}{lccccccc}
\hline Kastamonu & 782616 & 3499 & 30904 & 15023 & 406036 & 710990 & 819 \\
Mersin & 181239 & 1 & 37634 & 40241 & 17759 & 173790 & 1525 \\
Muğla & 323740 & 1870 & 43492 & 52552 & 90817 & 312857 & 69 \\
Trabzon & 43482 & 1 & 10430 & 2369 & 47731 & 9598 & 21 \\
Zonguldak & 470954 & 104 & 4751 & 55580 & 186685 & 383575 & 76 \\
Kütahya & 164140 & 8264 & 39184 & 6815 & 111602 & 262663 & 1487 \\
Konya & 21370 & 1 & 4961 & 14792 & 10270 & 50884 & 74 \\
& & & & & & & \\
\hline
\end{tabular}

\section{Method}

Clustering Analysis

Clustering analysis is the process of creating clusters, which is defined as a cloud analogy of similar objects (units) in multidimensional space (Y1lmaz and Patır, 2011). The main purpose of clustering analysis is to classify ungrouped data into homogeneous groups according to their similarities. For this purpose different distance measures are used and clusters are formed (Giray, 2013). Squared Euclidean distance measure was used in the study.

The selection of appropriate clustering algorithms is critical to the effective use of cluster analysis. The clustering algorithm is divided into hierarchical and non-hierarchical clustering analysis. The hierarchical clustering analysis was used in the study. The hierarchical clustering is a series of steps that build a tree-like structure by either adding individual elements to or deleting them from clusters (Tekin, 2015; Ketchen and Shook, 1996). In hierarchical clustering techniques, the number of clusters can be visually decided by using dendrogram. Dendrograms resemble decision trees with short "limbs" that represent the joining of observations (Çakmak, 1999; Ketchen and Shook, 1996).

\section{Discriminant Analysis}

Discriminant analysis is a method that allows comparison of two or more groups depending on a large number of variables. In other words, discriminant variables are those variables which indicate the difference between the groups (Oğuzlar 2006; Filiz and Yaprak 2009). The discriminant analysis is similar to the clustering analysis. However, while classes are not known before hand in the clustering analysis, these classes are known before hand in the discriminant analysis (Akyüz, 2006).

\section{Findings and Results}

In this study, clustering analysis was performed by Ward method. Firstly, the number of clusters was analyzed without specifying the number of clusters. Then, the clustering in which the highest achievement was achieved with the help of discriminant analysis was determined. The obtained dendogram was given in Figure 2.

When the dendogram was examined, it was determined that the regional directorates of forestry could be divided into maximum 6 and minimum 2 groups. As a result of the discriminant analysis, the highest success rate was found when all samples were divided into 6 different groups at the $p<0.05$ significance level. The regional directorates of forestry of the identified groups are given in Table 3. 


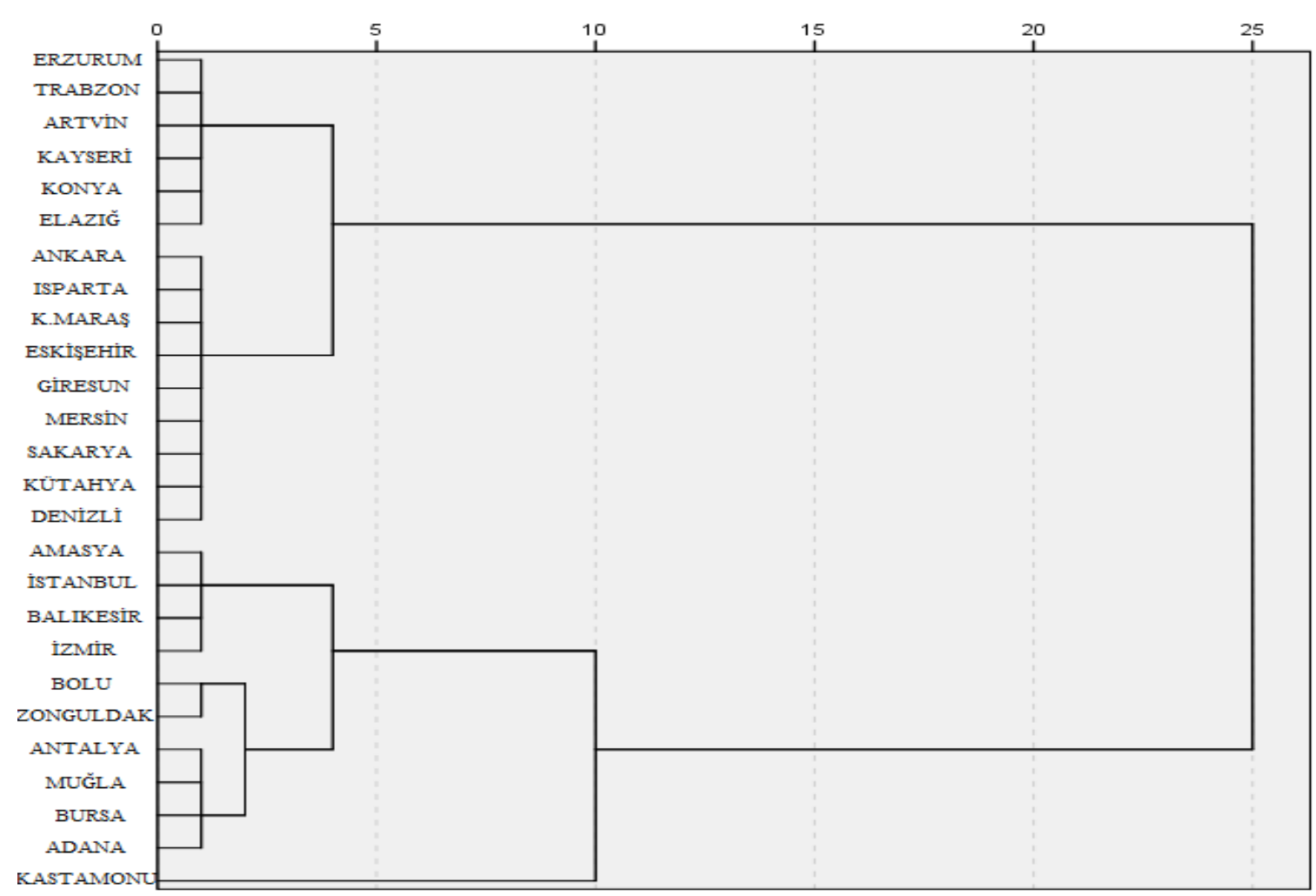

Figure 2. Dendogram of Regional Forest Directorates

The clusters formed as a result of the hierarchical clustering analysis can also be interpreted through the agglomerative table. In this table, the regional directorates of forestry most similar to each other according to coefficients of industrial wood variables are matched. In the agglomerative table, the number of stages is n-1. " $n$ "refers the number of observations. According to Table 2, the regional directorates of forestry, which are most similar to each other, are: (1) ErzurumTrabzon, (2) Kayseri-Konya, (3) AnkaraIsparta and so on., while the ones least similar to each other are: (1) Adana-Sakarya, (2) Adana-Kastamonu, (3) Sakarya-Artvin and so on.

Table 2. Agglomeration Schedule

\begin{tabular}{cccccccc}
\hline \multirow{2}{*}{ Stage } & \multicolumn{2}{c}{ Cluster Combined } & \multirow{2}{*}{ Coefficients } & Stage & \multicolumn{2}{c}{ Cluster Combined } & \multirow{2}{*}{ Coefficients } \\
\cline { 2 - 3 } \cline { 6 - 7 } & Cluster 1 & Cluster 2 & & Cluster 1 & Cluster 2 & \\
\hline 1 & Erzurum & Trabzon & 413872844.5 & 14 & Antalya & Bursa & 44818319135.3 \\
\hline 2 & Kayseri & Konya & 884884039 & 15 & Sakarya & Giresun & 54490916127.3 \\
\hline 3 & Ankara & Isparta & 2469309600 & 16 & Balıesir & İzmir & 64287330805.3 \\
\hline 4 & Antalya & Muğla & 4163782708.9 & 17 & Bolu & Zonguldak & 75304555115.8 \\
\hline 5 & Artvin & Erzurum & 5888384893.8 & 18 & Adana & Antalya & 90991154266.9 \\
\hline 6 & Kayseri & Elazığ & 7863192024.7 & 19 & Amasya & Balıesir & 109116871215.6 \\
\hline 7 & Ankara & K.Maraş & 10527761905.7 & 20 & Sakarya & Ankara & 140173176220.7 \\
\hline 8 & Giresun & Mersin & 13265133271.2 & 21 & Adana & Bolu & 216727897260.4 \\
\hline 9 & Sakarya & Kütahya & 16844982636.7 & 22 & Adana & Amasya & 354181577882.3 \\
\hline 10 & Artvin & Kayseri & 21193940570.8 & 23 & Sakarya & Artvin & 508267483030.1 \\
\hline 11 & Sakarya & Denizli & 26646517154.7 & 24 & Adana & Kastamonu & 888875132670.4 \\
\hline 12 & Ankara & Eskişehir & 32393373894.2 & 25 & Adana & Sakarya & 1872190919400.8 \\
\hline 13 & Amasya & İstanbul & 38455069033.7 & & & & \\
\hline
\end{tabular}


Looking at Table 3, Kastamonu regional directorate of forestry forms a different cluster. In other words, Kastamonu regional directorate of forestry is different from other regional directorates in terms of industrial wood production. The cluster of other regional directorates of forestry is as follows:

Cluster 1: Adana, Antalya, Bursa and Muğla
Cluster 2: Sakarya, Ankara, Denizli, Eskişehir, Giresun, Isparta, K.Maraş, Mersin and Kütahya

Cluster 3: Amasya, Balıkesir, İstanbul and İzmir

Cluster 4: Artvin, Kayseri, Elazığ, Erzurum, Trabzon and Konya

Cluster 5: Bolu and Zonguldak

Cluster 6: Kastamonu

Table 3. According to the results of the ward test, clusters formed by the regional directorates of forestry

\begin{tabular}{|c|c|c|c|c|c|c|}
\hline Clusters & 1 & 2 & 3 & 4 & 5 & 6 \\
\hline \multirow{9}{*}{$\begin{array}{l}\text { Regional } \\
\text { Directorates of } \\
\text { Forestry }\end{array}$} & Adana & Sakarya & Amasya & Artvin & Bolu & Kastamonu \\
\hline & Antalya & Ankara & Balıkesir & Kayseri & Zonguldak & \\
\hline & Bursa & Denizli & İstanbul & Elazığ & & \\
\hline & Muğla & Eskişehir & İzmir & Erzurum & & \\
\hline & & Giresun & & Trabzon & & \\
\hline & & Isparta & & Konya & & \\
\hline & & K. Maraş & & & & \\
\hline & & Mersin & & & & \\
\hline & & Kütahya & & & & \\
\hline
\end{tabular}

As a result of this clustering, cluster mean values of telephone pole, and pole variables were not significant at the $5 \%$ significance level in the equality test (Table 4) and it was found that the other 5 variables were significant. As Wilks' lambda value approaches to 1, the effect of variables on the discrimination of groups decreases (Güzeller and Kelecioğlu, 2006). To discriminate the clusters, $\log$ and fibre-chipwood variables are more effective than other variables.

Table 4. Tests of equality of group means

\begin{tabular}{lccc}
\hline Variables & Wilks' Lambda & F & Sig. \\
\hline Log & 0.049 & 77.254 & 0.000 \\
\hline Telephone pole & 0.930 & 0.303 & 0.905 \\
\hline Mining pole & 0.512 & 3.807 & 0.014 \\
\hline Other industrial wood & 0.487 & 4.209 & 0.009 \\
\hline Pulpwood & 0.179 & 18.365 & 0.000 \\
\hline Fibre-chipwood & 0.052 & 73.543 & 0.000 \\
\hline Pole & 0.687 & 1.818 & 0.155 \\
\hline
\end{tabular}

In Figure 3, the centers of the six clusters and the distances of the cluster elements from the centers are observed. According to Figure 3, while the second and fourth clusters are the closest clusters, the fourth and sixth clusters are the most distant clusters to each other. The values of the distance values between the clusters were calculated to support the graph of canonical discriminant functions (Table 5). The results of distance value and Canonical discriminant functions graph are similar to each other 


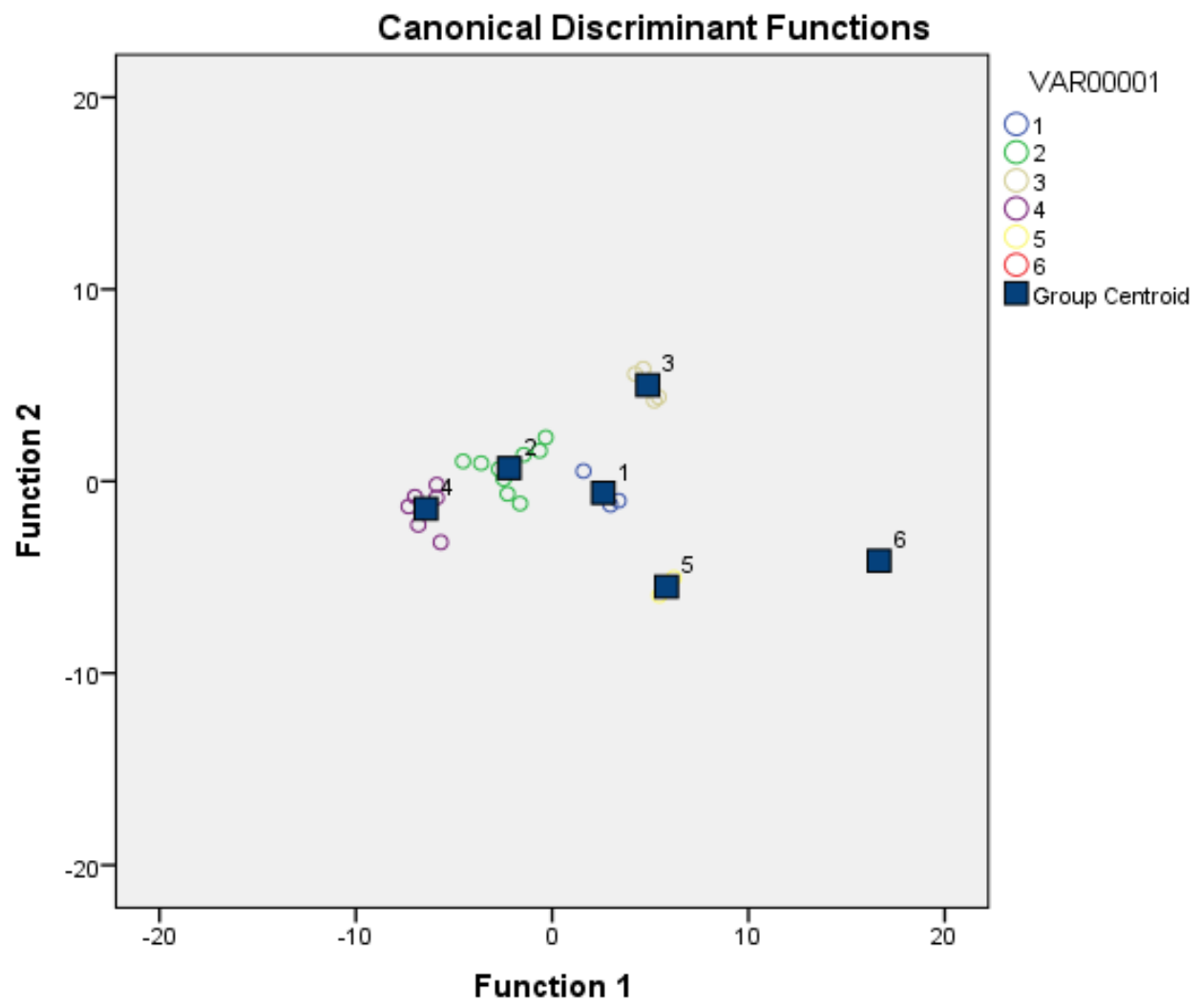

Figure 3. Distribution of cluster centers and cluster elements according to the discriminant function

Table 5 . The distance values between the clusters

\begin{tabular}{ccccccc}
\hline & 1 & 2 & 3 & 4 & 5 & 6 \\
\hline 1 & 0.0000 & 32.7105 & 43.0359 & 87.9240 & 42.5360 & 226.8277 \\
\hline 2 & 32.7105 & 0.0000 & 70.2413 & 24.0144 & 104.7493 & 380.2448 \\
\hline 3 & 43.0359 & 70.2413 & 0.0000 & 169.1847 & 111.5089 & 228.0457 \\
\hline 4 & 87.9240 & 24.0144 & 169.1847 & 0.0000 & 167.3358 & 545.0479 \\
\hline 5 & 42.5360 & 104.7493 & 111.5089 & 167.3358 & 0.000 & 125.2786 \\
\hline 6 & 226.8277 & 380.2448 & 228.0457 & 545.0479 & 125.2786 & 0.0000 \\
\hline
\end{tabular}

The comparisons of group mean values of the variables that are effective in the formation of groups as a result of the analyses were given in Table 6 .

Table 6. The mean values of groups

\begin{tabular}{lcccccc}
\hline Variables & 1.Cluster & 2.Cluster & 3.Cluster & 4.Cluster & 5.Cluster & 6.Cluster \\
\hline Log & 306773.25 & 135834 & 215268.25 & 40459.83 & 477932 & 782616 \\
\hline Telephone pole & 1272 & 2225.67 & 816.25 & 1606.83 & 1839 & 3499 \\
\hline Mining pole & 48201.75 & 23016.11 & 26076 & 7646.83 & 8301 & 30904 \\
\hline $\begin{array}{l}\text { Other industrial } \\
\text { wood }\end{array}$ & 62972.25 & 17416.44 & 60787.50 & 4169.67 & 30621 & 15023 \\
\hline Pulpwood & 93831 & 51506.56 & 95498 & 20608.83 & 244025 & 406036 \\
\hline Fibre-chipwood & 290346.25 & 202956 & 489223.75 & 23127.33 & 344415.50 & 710990 \\
\hline Pole & 107.75 & 793.33 & 236.5 & 231.83 & 191 & 819 \\
\hline
\end{tabular}


If we examine the findings in Table 6,

(1) Regarding of $\log$, telephone pole, pulpwood, fibre-chipwood productions and pole, it was found that the cluster having the highest production is 6th.

(2) Regarding of mining pole and other industrial wood productions, the highest cluster is 1 th cluster.

(3) Regarding of log, mining pole, other industrial wood, and pulpwood and fibre- chipwood productions, cluster having the lowest production is 4 th cluster.

(4) The clusters having lowest telephone pole and pole productions are 3th and 1th clusters, respectively.

In addition, Table 7 has been used to determine whether the Forest District Directorates efficiently utilize forest areas in the production of industrial wood or not.

Table 7. Distribution of forest land according to the regional directorates of forestry (Anonymous, 2015)

\begin{tabular}{lclclc}
\hline $\begin{array}{c}\text { Regional } \\
\text { Directorates }\end{array}$ & $\begin{array}{c}\text { Total } \\
\text { (hectar) }\end{array}$ & $\begin{array}{c}\text { Regional } \\
\text { Directorates }\end{array}$ & $\begin{array}{c}\text { Total } \\
\text { (hectar) }\end{array}$ & $\begin{array}{c}\text { Regional } \\
\text { Directorates }\end{array}$ & $\begin{array}{c}\text { Total } \\
\text { (hectar) }\end{array}$ \\
\hline Adana & 742495 & Kayseri & 619634 & K.Maraş & 869129 \\
\hline Sakarya & 351453 & Denizli & 812168 & Kastamonu & 1239498 \\
\hline Amasya & 1529275 & Elaziğ & 1287620 & Mersin & 840470 \\
\hline Ankara & 775167 & Erzurum & 541924 & Muğla & 1156983 \\
\hline Antalya & 1146062 & Eskişehir & 637836 & Trabzon & 641324 \\
\hline Artvin & 403695 & Giresun & 560810 & Zonguldak & 606309 \\
\hline Balikesir & 649115 & Isparta & 768816 & Kütahya & 646552 \\
\hline Bolu & 628548 & Istanbul & 637364 & Konya & 704058 \\
\hline Bursa & 761597 & Izmir & 1010558 & & \\
\hline
\end{tabular}

Although the Amasya regional directorate that has most forest land, regarding of industrial wood production is the Amasya regional directorate of forestry, it is the same cluster as Balıkesir and İstanbul regional directorates of forestry. These regional directorates have about half of the forest land that Amasya regional directorate owns. Although Elazı $\breve{g}$ regional directorate has a very high forest area, the production of industrial wood is very low. Although Eastern Black Sea Region is known as area that has the high forest, the regional directorates of forestry in Eastern Black Sea Region are not in good condition in terms of industrial wood production. In other words, it is seen that regional directorates of forestry in Eastern Black Sea Region such as Elazı $\breve{g}$ and Amasya regional directorates do not use forest areas effectively. The Sakarya regional directorate of forestry is in the same group with other forest regional directorates which is more than 2 times higher than the Sakarya regional directorate in terms of forest area. It is seen that the regional directorates of forestry that use the forest area most efficiently are Kastamonu, Zonguldak and Bolu regional directorates of forestry.

\section{Conclusion}

As can be seen from all these analyses, Kastamonu regional directorate of forestry has an important advantage than other regional directorates in the production of industrial wood. Kastamonu regional directorate of forestry has formed a different group because of the high production of $\log$, pulpwood and fibre-chipwood. In other words, the Regional Directorate of Forestry, which produces the highest industrial wood, is Kastamonu. This is followed by Bolu and Zonguldak the Regional Directorates of Forestry.

The log production was found to be the most effective variable in the discriminant function. This variable is followed by fibrechipwood variable. Regarding of industrial wood production, it ectorate of forestry and the regional direwas found that the Kastamonu regional dirctorates of forestry in 
the 4th cluster are the most distant regional directorates to each other.

In general, it is seen that the regional directorates of forestry, which are close to each other in terms of forest land, are in the same group in terms of industrial wood production.

Although Turkey in the production of fibreboard and particleboard are in the top 3 list in Europe, the level of industrial wood production and quality, which is the raw material of these products, is not the desired level. The vast majority of industrial wood imports come from Russia. However, with the new forest law applied in Russia, very high taxes are applied for wood exports. Therefore, the amount of industrial wood that we import from Russia is likely to decline in the future (Anonymous, 2016). We have to increase our production of wood in terms of quality and quantity. The necessary precautions such as emphasis on forest maintenance, employment of personnel, new methods and practices, reforestation of coppice forests must be taken for this. The equipment needed to keep the forest roads open all year round is required to be renewed and forest roads should be built. Also, the costs of purchasing raw materials must be reduced so that the forest products industry can compete in international markets.

\section{References}

Akyüz, K.C. (2006). Competition of forest products industry during to European Union membership. ZKÜ Bartın Journal of Forest Faculty, 8(9), 83-94.

Akyüz, K.C., Balaban, Y. \& Yıldırım, İ. (2012). Evaluation of financial structure of forest products industry by means of balance sheet ratios. International Journal of Economic and Administrative Studies, 58(9), 133-144.

Akyüz, K.C., Cindık, H., Akyüz, İ. \& Serin, H. (2002a). Role of forest product industry development on Eastern Black Sea region. Kafkas University Journal of Artvin Forestry Faculty, 1, 24-32.

Akyüz, K.C., Cindık, H., Serin, H. \& Akyüz, İ. (2002b). Investigation of exports and imports total prices of forest product industry in the East Black Sea region. Kafkas University Journal of Artvin Forestry Faculty, 1, 10-16.

Akyüz, K.C. \& Yildırım, İ. (2009). Paper and paper board industry in Turkey and European Union countries. Kastamonu Univ., Journal of Forestry Faculty, 9(2), 86-94.
Akyüz, K.C., Yıldırım, İ., Tugay, T., Akyüz, İ. \& Gedik, T. (2016). A cluster and discriminant analysis of sub-sectors of manufacturing based on the occupational accident statistics. Journal of Forestry, 12(1), 18-29.

Alem, S. (2016). Status and trends of the processed wood products trade in Ethiopia. Journal of Sustainable Forestry, 35(4), 251260.

Anonymous, (2015). The presence of forests in Turkey. Rebublic of Turkey General Directorate of Forestry, Ankara.

(https://www.ogm.gov.tr/ekutuphane/Yayinlar/T $\%$ C3\%BCrkiye\%20Orman\%20Varl\%C4\%B1 $\% \mathrm{C} 4 \% 9 \mathrm{~F} \% \mathrm{C} 4 \% \mathrm{~B} 1-2016-2017 . p d f)$

Anonymous, (2016). Production and marketing of wood-based forest products. General Directorate of Forestry, Department of Management and Marketing, Ankara.

Bojnec, S. \& Fertö, I. (2011). Trade in raw and semi-finished wood products of Hungary and Slovenia with Austria. Austrian Journal of Forest Science, 3, 157-176

Bojnec, S. \& Fertö, I. (2014). Forestry industry trade by degree of wood processing in the enlarged European Union countries. Forest Policy and Economics, 40, 31-39.

Çakmak, Z. (1999). Evaluation of clustering results and the validity problem in clustering analysis. Dumlupinar Uni., Journal of Social Siences, 3, 187-205.

Filiz, Z. \& Yaprak, B. (2009). A study on classifying parenting styles through discriminant analysis. Journal of Theory and Practice in Education, 5(2), 195-209.

GDF (2015). Turkey Forest Assets 2015. General Directorate of Forestry, Ministry of Forestry and Water Affairs, Ankara.

GDF (2017). Production, sales and stock activities. Republic of Turkey General Directorate of Forestry, Ankara.

(https://www.ogm.gov.tr/ekutuphane/Uretim Satis ve Stok Faaliyetleri/Forms/All Items.aspx)

Giray, S. (2013). Classification of countries according to their tourism statistics via different cluster analysis methods and the place of Turkey in this structure. International Conference on Eurasian Economies, 17-18 September, Rusia, 695-704.

Güngör, İ., Kayacan, M.C. \& Korkmaz, M. (2004). Artificial neural networks use in the forecasting of industrial wood demand and comparison with different estimation methods. Operations Research and Industrial Engineering XXIV. National Congress, Çukurova University, 15-18 June, Adana, Turkey.

Güzeller, C. \& Kelecioğlu, H. (2006). The study on classification validity of secondary education student selection \& placement 
exam. H.U. Journal of Education, 30, 140148.

KetchenJr, D.J. \& Shook, C.L. (1996). The application of cluster analysis in strategic management research: an analysis and critique. Strategic Management Journal, 17(6), 441-458.

Koebel, B.M., Levet, A.L., Van, P.N., Purohoo, I. \& Guinard, L. (2016). Productivity, resource endowment, and trade performance of the wood product sector. Journal of Forest Economics, 22(C), 24-35.

Maxir, H.D.S. \& Masullo, L.S. (2017). The Brazilian insertion into the International trade of forest products chain. Revista Árvore, 41(3), 1-12.

Oğuzlar, A. (2006). Assessment of house hold type and rural-urban area distinctions by means of discriminant analysis. Journal of Akdeniz I.I. ..B.F, 11, 70-84.

Palus, H., Parobek, J. \& Liker, B. (2015). Trade performance and competitiveness of the Slovak wood processing industry within the visegrad group countries. Drvna Industrija, 66(3), 195-203.

Sujova, A., Hlavackova, P. \& Marcinekova, K. (2015). Measuring the impact of foreign trade on performance growth of the wood processing industry. Wood Research, 60(3), 491-502.
Tekin, B. (2015). Grouping of cities in terms of primary health indicators in Turkey: an application of cluster analysis. Çankırı Karatekin University Journal of The Faculty of Economics and Administrative Sciences, 128.

Tiryaki, S., Aydın, A. \& Üçüncü, K. (2015). Investigating foreign trade situation of Turkish furniture sector in process of European Union by cluster analysis. Selçuk Journal of Technical, Special Issue-1, 938949.

URL-1 (2017). Our forests and benefits. https://www.ogm.gov.tr/ekutuphane/Yayinlar/ Orman $\% \mathrm{C} 4 \% \mathrm{~B} 1 \mathrm{n} \% 20 \mathrm{Faydalar} \% \mathrm{C} 4 \% \mathrm{~B} 1 . \mathrm{pdf}$, Access date:20.08.2017.

URL-2 (2017).

https://www.ogm.gov.tr/ekutuphane/Sayfalar/Istat istikler.aspx,Accesdate: 20.08.2017.

Yıldırım, İ., Akyüz, K.C., Gedik, T., Balaban, Y. \& Çabuk, Y. (2008). Competitive power of Turkey with European Union countries in wood-based panel industry. Bartin Journal of Forest Faculty, 10(13), 11-22.

Yılmaz, S..K. \& Patır, S. (2011). Cluster analysis and its usage in marketing. Journal of Academic Approaches, 2(1), 91-113. 